\title{
Effects of Cross Shore Profiles on the Sustainable Design of Coastal Structures
}

Akram Soliman, Arab Academy for Science and Technology and Maritime transport, akram.soliman@pti-aast.or Saad Abdelrahman, Arab Academy for Science and Technology and Maritime transport, smesbah@aast.edu

Moheb Iskander, Coastal Research Institute, Alexandria, Egypt, coastal alex@yahoo.com

Nabil Ismail, Arab Academy for Science and Technology and Maritime transport, nbismail@usa.net

Figure 1: Reinforcement of beach profile by concrete revetment at Loran, Alexandria, Egypt.

\section{Introduction:}

The performance of the existing coastal structures at three different locations along Alexandria coastline, Egypt was re-examined.

- The first area "Shatby" has a narrow sandy beach that is protected by a vertical seawall of 3$5 \mathrm{~m}$ above sea water level.

- The $2^{\text {nd }}$ area "Sporting" was protected by a revetment of 25 width with $10 t$ concrete blocks.

- The $3^{\text {rd }}$ area "Loran", revetment protected the shoreline against further erosion with beach profile completely covered by blocks, (Figure1).

- The benefits of complementing the existing structures by adding limited modification are Investigated.

- Submerged Breakwater was applied in Mandara beach in 2009. Figure 2 shows its good effect.

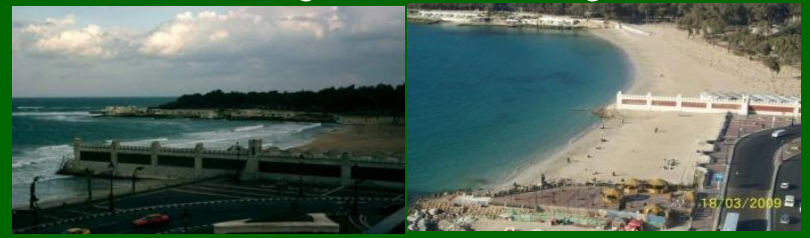

Figure 2: Effect of submerged breakwater in beach width at Mandra beach, Alexandria.

\section{Methods:}

- Profiles' surveying were carried out from a constructed land baseline to a water depth of $10.0 \mathrm{~m}$ below the M.W.L.

- Two dimensional Reynolds-Averaged NavierStokes (RANS) numerical model has been used (Reeve et el., 2008, Lin and Xu, 2006).

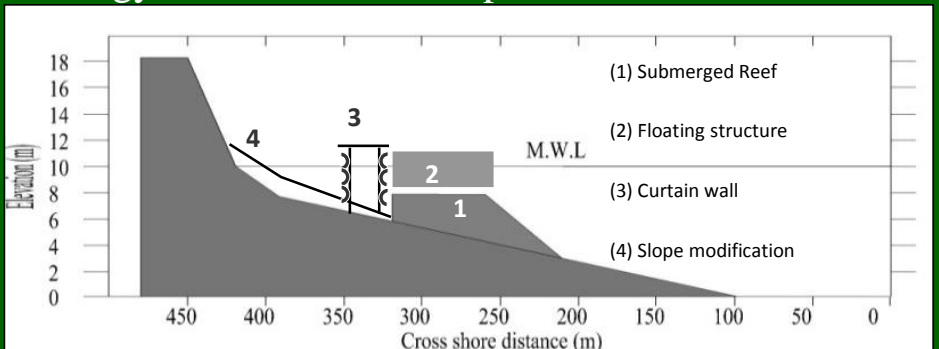

Figure 3: Cross section of the sloped beach with the proposed structures at Sporting.

\section{Results:}

- Four coastal protection schemes were investigated; submerged Reef, Floating structure, Curtain wall and slope modification (Figure 3).

- Wave characteristics used at the surveyed profiles are: $\mathrm{Hs}=1.00 \mathrm{~m}, \mathrm{Tm}=6.0 \mathrm{~s}$.

- Their effects on the reduction of wave breaking heights, wave run-up as well as maintaining nourished sandy beaches is evaluated (Figure 4).

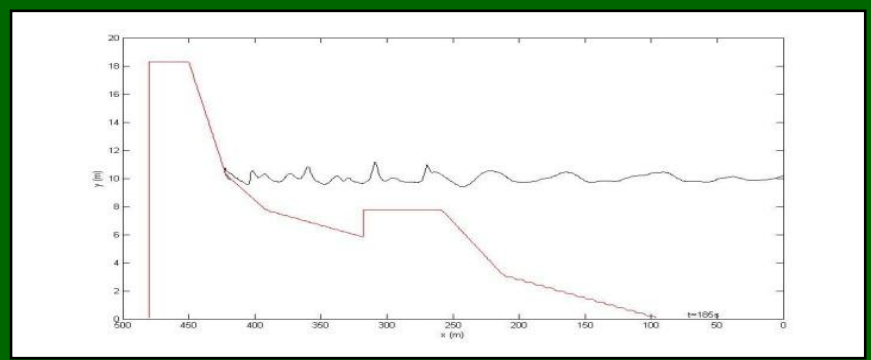

Figure 4: Snapshot of the free surface at Sporting with the proposed submerged artificial reef.

\section{Analysis:}

- Table 1 shows a comparison between the values of wave run-up for the nature beach profile and after the construction of the submerged artificial reef. The numerical model results showed the reduction of wave run-up (20\%) .

\begin{tabular}{|c|c|c|}
\hline Location & $\begin{array}{c}\text { Wave run-up } \\
(\mathrm{m})\end{array}$ & $\begin{array}{c}\text { Wave run-up with AR } \\
(\mathrm{m})\end{array}$ \\
\hline Shatby & 0.14 & 0.11 \\
\hline Sporting & 0.13 & 0.10 \\
\hline Loran & 0.13 & 0.12 \\
\hline
\end{tabular}

\section{References:}

- El-Sharnouby and Soliman (2011): Behavior of Shore Protection Structures at Alexandria, Egypt, during the Storm of December 2010, Proceedings of the 2011 Conference on Coastal Engineering Practice, San Diego, California, ASCE, USA, pp. 780-792.

- Lin and Xu (2006): NEWFLUME: a numerical water flume for two dimensional turbulent free surface flows, Journal of Hydraulic Research, vol. 44 (1), pp. 79-93.

- Reeve, Soliman, and Lin (2008): Numerical study of combined overflow and wave overtopping over a smooth impermeable seawall. Coastal Enaineering. ELSEVIER, vol. 55(2). pp. 155-166. 